\title{
Det kannibalske øje: virkelighedsshow, eksperiment- fjernsyn og den nye kreativitet i fjernsynsunderholdningen
}

\section{Af Arild Fetveit}

Artiklen diskuterer to nye tendenser $i$ 1990'ernes tv: virkelighedsshowene i form af programmer om politi- og redningsarbejde, som vandt frem i forste halvden af artiet, og eksperimentformater, som med Big Brother fik stor popularitet sidst $i$ årtiet. I virkelighedsshowene foretages en rekontekstualisering af faktamaterialet, som suakker dets referentialitet, og dokumentarismen andrer karakter fra information til underholdning. Eksperimentfjernsynet går endnu videre, idet kategorierne fakta og fiktion oploses til fordel for et socialt eksperiment i et iscenesat laboratorium. Afslutningsvist argumenterer artiklen for, at de to reality-formater er falles om at indbyde til en ny måde at se to på-det kannibalistiske oje. Dette blik aflaser en empatisk betragtning og er dermed symptomatisk for det test- og overvågningssamfund, som forfatteren ved hjalp af kulturkritisk teori (Benjamin, Debord) skitserer omridsene af.

Five years after O. J. Simpson set out in his Ford Bronco, the televised chase is a staple of Los Angeles life. Some enthusiastic viewers like to think of it as performance art of the pavement. (Deanne Stillman, The New Tork Times)

You're not anybody in America unless you're on TV. On TV is where we learn about who we are. Because what's the point of doing anything worth while if nobody's watching? And if people are watching it makes you a better person. (Suzanne Stone spilt av Nicole Kidman i To Die For, 1995)

Menneskehetens fremmedhet overfor seg selv har nådd så langt at den er i stand til å oppleve sin egen tilintetgjørelse som estetisk nytelse av første rang. (Walter Benjamin, Kunstverket i reproduksjonsalderen).

Da filmen kom, representerte den på mange måter et virkelighetssjokk. Som Georges Méliès sa etter brødrene Lumières første offentlige filmfremvisning, »we sat with gaping mouths, struck with amazement, astonished beyond all expression « (sitert i Gunning 1995:119). Fremvisningen av virkeligheten i levende bilder var i seg selv sugge- rerende, men ganske snart søkte man til spesielle attraksjoner. Blant tidlige filmtitler finner vi Life of an American fireman (Edison 1902-1903), Tracked by bloodhounds; or, A lynching at Cripple Creek (Selig 1904), sistnevnte markedsført som «the most sensational picture ever made« (sitert i Musser 1994: 398). Redningsaksjoner og jakt på forbrytere var altså blant attraksjonene som ble tilbudt. Filmskapere kunne også arrangere mindre eksperimenter. Ikke alle var like smakfulle. Erik Barnouw forteller om Martin Johnson hvis »idea of humor was to give a pygmy a cigar and wait for him to get sick« (Barnouw 1983:51).

I forbindelse med den tidlige filmens søken etter umiddelbar fascinasjon gjennom spektakulære hendelser, snakker Tom Gunning om »a cinema of attractions«, en film som »directly solicits spectator attention, inciting visual curiosity, and supplying pleasure through an exciting spectacle [...] that is of interest in itself« (Gunning 1990:58). Andre halvdel av det 19 århundre »lives in a sort of frenzy of the visible«, hevder Jean-Louis Comolli, »the whole world becomes visible at the same time that it becomes appropriatable« (Comolli 1980: 122f). Filmen kommer i en tid hvor grensen for det som kan visualiseres og representeres radikalt 
utvides. Den bidrar selv til å videreføre denne »frenzy of the visible« gjennom en estetikk som »envisioned cinema as a series of visual shocks« (Gunning 1995:116) hvor også de mest intime områder ble åpnet for kamera gjennom pornografiske filmer som Wonders of the Unseen World (1927) (se Williams 1989).

I dagens virkelighetsshow danner røffe dramatiske bilder fra virkelige ulykker og arrestasjoner et ekko av dette virkelighetssjokket i programmer som Cops, LAPD: Life on the beat, Real TV, Rescue 911, I Witness Video ${ }^{~}$. Amatørvideo, overvåkningskamera og billig utstyr har sammen med kommersielt press bidratt til at kamera påny har utvidet sitt virkefelt. Virkelighetsshowene hadde en gylden tid på 1990-tallet, men mot slutten av tiåret fikk disse formatene basert på politi og redningsarbeid en stadig mer marginal plass på sendeskjemaene. Til gjengjeld fikk vi en beslektet variant, det jeg i det følgende vil kalle eksperimentfjernsynet - siden det er basert på et sosialt/psykologisk/seksuelt eksperiment med mennesker ${ }^{2}$. Med formatet Big Brother kunne prime time gjenerobres og en revolusjonerende modell for samvirke mellom fjernsyn, nett- og telefontjenester lanseres ${ }^{3}$. Ulykker eller politijakter er ikke attraksjonen denne gang, men et video-overvåket sosialt eksperiment hvor 10 unge kvinner og menn lukkes inne $\mathrm{i}$ et spesialkonstruert hus i 100 dager hvor de blant annet må dele soverom og senger. De nominerer hverandre til å bli stemt ut. Publikum stemmer dem så ut en etter en, og kårer til slutt en millionær. Dermed har vi et hybridformat som involverer et gameshow-element, et element av såpeoperaens konflikter og kjærlighetsrelasjoner, et dokumentarisk element, samt interaksjon med publikum gjennom stemmegivning.

Det har blitt hevdet at virkelighetsshowene utfordrer distinksjonen mellom fakta og fiksjon (Kilborn 1994), hvilket også kan synes å gjelde for eksperimentfjernsynet. For virkelighetsshowenes del kunne en for eksempel tenke seg at dette skjer ved at autentiske og dramatiserte opptak blandes, eller gjennom at såpeoperaens dramaturgi brukes i formidling av faktastoff. Det er imidlertid andre trekk ved den måten formatene relaterer til virkeligheten på som kan være vel så interessante. Jeg vil særlig for virkelighetsshowenes del fokusere på hvordan deres forhold til virkeligheten, hvordan deres referanse, er ulik dokumentarfilmens. Spørsmålet om hvordan fakta- og fiksjonskate- goriene utfordres står mer sentralt når jeg ser på eksperimentformatet Big Brother.

For virkelighetsshowenes del vil jeg i det følgende argumentere for at rekontekstualiseringen av faktamaterialet, samt en funksjonsendring fra informasjon til underholdning, virker i retning av å suspendere og innskrenke faktamaterialets referanse. Når det gjelder eksperimentformatet Big Brother forsøker jeg å vise at det tilsynelatende sammenbruddet mellom fakta og fiksjon bringer diskursen hinsides både fakta og fiksjon og inn $\mathrm{i}$ en performativitet som reduserer begge kategorienes relevans. Til sist argumenterer jeg for at både virkelighetsshowene og eksperimentformatet Big Brother inviterer til et kannibalsk blikk.

\section{Referansetap i virkelighetsshowene}

Det er en selvmotsigende dimensjon i begrepet virkelighetsshow siden show gjerne forbindes med avkobling fra virkeligheten. Det er også rimelig å reise spørsmål ved hvordan virkeligheten representeres i programmer som Cops, LAPD og Real TV. Det kan for eksempel være interessant å sammenligne et par episoder av LAPD med den kritiske PBS Frontline-dokumentaren LAPD Blues (Michael Kirk \& Rick Young 2001) som blant annet belyser korrupsjon i Los Angeles Police Department. Et slikt portrett av politiet rimer ikke så godt med den besteborgerlige lov- og ordenideologien virkelighetsshowene gjerne fremmer (se Fetveit 2002). Hvordan skiller så disse formatene seg fra dokumentarfilmen når det gjelder referanse og argumentasjon?

»Photographic images are always of concrete, material things recorded at specific moments in time«, sier Bill Nichols, »but are often made to point toward more general truths and issues« (Nichols 1994:2). Slik fungerer vanligvis argumentasjonen i audiovisuelle faktasjangere. Konkret materiale brukes i argumenter om mer allmene forhold. Imidlertid kan materialet i seg selv være nokså fattig på interessant informasjon. Bertolt Brecht påpeker at de konkrete detaljene kameraet fanger opp ikke nødvendigvis er i stand til å avdekke det vesentlige.

En enkel gjengivelse av virkeligheten utsier mindre om virkeligheten enn noensinne. Et fotografi av Krupp-verkene eller av A.E.G. utsier nesten 
ingenting om disse institusjonene. Den egentlige virkelighet har glidd over i det funksjonelle [...] Det gjelder altså faktisk å bygge opp noe, noe kunstig, noe oppstilt. (Brecht sitert i Benjamin 1991:78)

Walter Benjamin så utviklingen av en filmatisk montasjeteknikk (samt bruk av tekst) som svar på denne utfordringen (ibid.). Det var også i den filmiske montasje, ikke minst i Sergei M. Eisensteins realistiske filmer fra 1920-tallet, særlig Panserkrysseren Potempkin (1925) og Streik (1925), at John Grierson søkte inspirasjon til å utvikle en dokumentarfilm som kunne bringe »the affairs of our time [...] to the screen « (Grierson 1947:13) og tilby et forum for »our new teaching of citizenship« (ibid.:10). Denne politiske interessen for representasjoner av virkeligheten som kan vitalisere offentligheten er fraværende i virkelighetsshowene. Som Nichols sier: »Documentary film had a vested interest in our behavior and disposition beyond the theater. Reality TV has a vested interest in subsuming everything beyond itself into its own support system of circulating exchange values« (Nichols 1994:54).

Formatene er basert på en omdefinering av dokumentariske bilders funksjon fra informasjon til underholdning ${ }^{4}$. I følge Nichols baserer de seg på en radikal rekontekstualisering hvor »everything can be ripped from its historical ground and contained [...] everything is up for grabs in a gigantic reshuffling of the stuff of everyday life (ibid.: 43). Dette gjør at »Reality TV [...] keeps reality at bay«, hevder Nichols, "reference to the real no longer has the ring of sobriety that separates it from fiction. Such reference now is a fiction« (ibid.:54).

Marginaliseringen av informasjonsfunksjonen gjør noe med det referensielle feltet, det felt av virkeligheten vi finner det relevant å relatere materialet til. Informasjonsfunksjonens forvitring bidrar til å forskyve fokus fra mer allmene analyser, argumenter og innsikter til partikulære fragmenter - gjerne til de audiovisuelle opptakene selv - noe som kan gi spørsmål om autentisitet større vekt. I denne bevegelsens kjølvann følger også det Nichols beskriver som reality TV's »ability to absorb the referent $[. .$.$] break the referent down into pa-$ latable confections that do not represent an absent referent so much as cannibalize and assimilate it into a different type of substance« (ibid.:52). Han snakker her om et særegent sammenbrudd i den audiovisuelle diskursen hvor bilder (tidvis også lydopptak) ikke lenger blir informasjonsbærende kommunikasjonsmidler som inngår i argumentative sammenhenger, men vendes til å fetisjere seg selv som relikvier fra den virkelighet som var foran opptaksutstyret. Det referensielle feltet de ellers kunne åpnet opp for suspenderes eller kommer i bakgrunnen. På det overliggende argumentasjonsnivå begrenser virkelighetsshowene seg til korte sentenser som uttrykker de ulike innslagenes »moral«, samt generelle oppfordringer til å »stay tuned $\ll$.

Dette er i følge Nichols en tendens som også i en viss utstrekning impliserer nyhetene.

The boundary between news and reality TV blurs as the news stresses audience participation in the ritual of news production itself rather than in the world outside the frame. Network news may well be said to present the news of the day as attractions offered by anchor/showpeople.... The news makes vicarious participation in the news show a higher priority than decision making and responsible action. Reality TV raises vicarious participation to an art. (ibid.:49)

Følgen blir at »social responsibility dissolves into tele-participation « (ibid.:53) ${ }^{5}$. Forbindelsen til nyhetssjangeren reiser spørsmål om virkelighetsshowene er like marginalisert som dagens programflate kan antyde, eller om deres bærende idé lever videre gjennom sin medvirkning til å redefinere fjernsynsnyheter, dokumentar- og naturprogrammer ${ }^{6}$.

I hvilken forstand representerer så denne delvise suspensjonen av referansen en fiksjonalisering? Snarere enn å hevde at suspensjonen innebærer en fiksjonalisering vil jeg hevde at den representerer et første skritt i retning av en fiksjonalisering - et skritt som også gir denne suspensjonen likheter med en estetisering. Monroe C. Beardsley beskriver estetiske objekter som »objects manqués« (Beardsley 1981:529). »There is something lacking in them«, sier han, »that keeps them from being quite real, from achieving the full status of things [...] upon this depends their capacity to call forth from us the kind of admiring contemplation, without any necessary commitment to practical action « (ibid.). I filmen Dial H-I-S-T-O-R-Y (1997) presser kunstneren Johan Grimonprez den estetiserende tendensen i virkelighetsshowene ytterligere ved å 
resirkulere TV-bilder fra flykapringer og ulykker. Til akkompagnement av easy-listening disco kan vi her blant annet nyte et fly fra Air France som i slow motion går inn for landing i en skog, for så å eksplodere når det treffer trestammene. Filmen fremprovoserer lett avskyreaksjoner på dette og lignende punkter. Grimonprez gjør seg nemlig skyldig i det han ønsker å kritisere. Han inntar både rollen som medskyldig og som dommer idet han gjør oss oppmerksomme på at dagens fjernsynskultur har gjort katastrofen til estetisert underholdning.

Nichols' kannibalmetafor er rettet mot den referensielle kortslutningen som oppstår når katastrofebildene på fjernsynet bare kommer til å omhandle og fetisjere seg selv i et intensivt forsøk på å holde vår interesse. Det ligger imidlertid også en annen kannibalisme her og det er den hvor andres skjebner blir vår symbolske næring, vår underholdning. Innsikten i denne symbolske økologien fikk Norske film- og tv-produsenters forening til å sammenkalle til debatt om »Kannibal-TV« 5. april 2000 i forkant av den norske Big Brother-produksjonen - for om kannibalismemetaforen er relevant i forhold til virkelighetsshowene er den ikke mindre aktuell i forbindelse med eksperimentfjernsynet.

\section{Fakta, fiksjon og det performative register}

Hybridformater som Big Brother reiser noen spesielle utfordringer med hensyn til å konseptualisere skillet mellom fakta og fiksjon, offentlig og privat. Jean Baudrillard drøfter sammenbruddet mellom offentlig og privat på en måte som indirekte knytter an til et sammenbrudd mellom fakta og fiksjon. Han snakker om hvordan både den private og den offentlige sfæren blir offer for en uthuling.

Both have ceased to be either spectacle or secret. The distinction between an interior and an exterior [...] has been blurred in a double obscenity. The most intimate operation of your life becomes the potential grazing ground of the media [...]. This is a microscopic pornography, pornographic because it is forced, exaggerated, just like the close-up of sexual acts in a porno film. All this destroys the stage, once preserved through a minimal distance and which was based on a secret ritual known only to its actors. (Baudrillard 1988:20f)

Baudrillard påtaler ikke bare her tendenser som er sterkt fremme i dagens eksperimentfjernsyn. Han påpeker også trekk som har vesentlige implikasjoner for en forståelse av fakta og fiksjon, nemlig sammenbruddet av distinksjonen mellom scene og sal, skuespillere og publikum. Når scenen ikke lenger er i det offentlige rom, men flyttes inn i det private, når aktørene ikke lenger er skuespillere, men «vanlige mennesker i uvanlige situasjoner « " bryter distinksjonen mellom scene og sal sammen og vi får det Baudrillard kaller obscenitet ${ }^{8}$.

Obscenity begins when there is no more spectacle, no more stage, no more theatre, no more illusion, when everything becomes immediately transparent, visible, exposed in the raw and inexorable light of information and communication.... It is no longer the obscenity of the hidden, the repressed, the obscure, but that of the visible, the all-to-visible, the more-visible-than-visible; it is the obscenity of that which no longer contains a secret and is entirely soluble in information and communication. (ibid.: 21f)

Baudrillard er opptatt av scenens, teaterets og illusjonens sammenbrudd i det intime hvor alt avdekkes og intet lenger er skjult. Det intime kan fremkalle et sammenbrudd både av fiksjons- og av faktadiskurser. Pornografien kan således punktere og erstatte filmens fiksjonsunivers med et performativt univers av virkelige kropper i aktivitet. Det dokumentariske univers, med sitt repertoar av argumenter og informasjon, kan også bryte sammen under vekten av pornografiens performativitet og insistering på kommunikativ nærhet. Verken når det gjelder skillet mellom det private og det offentlige, scene og sal, eller fakta og fiksjon dreier det seg her om en enkel blanding eller utydeliggjøring av grenser. Det er vel så mye snakk om en oppløsning av begge poler i det vi med Baudrillard kan kalle det obscene rom, det rom som verken er scene eller sal eller blandingen mellom dem, men hinsides begge og på samme tid obskønt. Hinsides fakta og fiksjon finner vi også det performative register. Fakta- og fiksjonsdiskurser kan oppløses og begrepsparet kan miste sin relevans ikke bare gjennom obsceniteten, men også gjennom det performative hvor vekten er forskjøvet fra å representere et fiktivt eller et faktisk univers til rett 
og slett å gjøre noe. Hvordan spilles så dette ut i eksperimentformatet Big Brother?

\section{Eksperiment, hybridisering og performativitet}

Big Brother's særegne dokumentarisme slekter på den vi kan finne i spektakulære naturprogrammer. Istedenfor å fotografere lirype, havørn eller perleugle i sine naturlige omgivelser - noe den norske zoolog og naturfotograf Sverre M. Fjellstad skapte seg et navn på - skaper man situasjonene man vil fotografere i en kontrollert eksperimentsituasjon. En termittkoloni plasseres ved siden av en maurtue $i$ et spesialbygd studio, noen løver bringes i nærheten av en antilopeflokk som har tre kameradekkede traseer de kan rømme langs - hvorfor ikke arrangere tilsvarende eksperimentsituasjoner med mennesker? Fordelen er at kameraet kan trenge dypere inn i den private sfære enn noen gang ${ }^{9}$. La ti fete menn og kvinner kappes om å vinne sitt vekttap i gull (The Big Diet), plasser fire par i et tropeparadis omgitt av beilere og se om de motstår fristelsen til å være utro (Temptation Island), eller putt ti mennesker i et hus i 100 dager - sett på kameraene og se hva som skjer.

Eksperimentsituasjonen med det spesialdesignede huset hvor man i den norske versjonen hadde et bad, to soverom, to senger for lite, felles boblebad og sauna, et medisinskap fullt av kondomer, rikelig tilgang på alkohol, dildo og pornoblader medbrakt av en deltaker som introduserte seg med replikken »er det noken knulling?«, samt en profesjonell stripper, ga klare føringer for hva man ønsket å stimulere internt i huset og hva slags attraksjon som kunne være i vente for publikum: virkelig sex. Ikke fordi Big Brother handler om sex. Big Brother handler liksom såpeoperaen først og fremst om relasjoner, men uten kjærlighet blir ikke relasjonene så sterke og pirrende, og uten løftet om sex blir det ingen pornografisk sensasjon å vente på ${ }^{10}$. Gjennom sammensetningen av deltakerne, avbrutt kontakt med omverden, regler for hva man kan snakke om, personlig rådgivning bak kulissene, instruksjoner om hva man skal ha på seg ved spesielle anledninger, ukesoppgaver etc, produseres en performativ adferd som kan dokumenteres og trekke seere.

En utfordring er å teoretisere og nærmere beskrive den performative handlingsmodus som produseres i eksperimentsituasjonen. Situasjonen legger opp til bestemte måter å presentere seg selv på, om man vil si det med Erwin Goffman (1959). Den produserer eller interpellerer subjekter på bestemte måter, om man vil si det med Michel Foucault (1975) eller Louis Althusser (1971). Performativitet, selvpresentasjon eller subjektkonstituering er imidlertid noe som skjer i enhver sammenheng. Utfordringen blir således å forstå på hvilke særlige måter det skjer i dette sosiale laboratoriet, som også er et slags fjernsynsstudio. Utvikling av en teoretisk og empirisk forståelse av hvordan risikerer imidlertid å bli vel så mye konseptutvikling for formatfabrikanten Endemol som å bli kritisk forskning ${ }^{11}$.

Vi har imidlertid ikke kun å gjøre med performative handlinger fra deltakerne og en dokumentering av denne. Produsenten bidrar også med performative innslag som skaper en multidiskursiv kompleksitet. Hinsides scene og sal gjeninnføres teater og forestilling som performativ lek. En tid etter at deltakerne i det norske Big Brother hadde hatt militæruke, hvor de måtte ta oppstilling utenfor huset i fullt feltantrekk til alle døgnets tider, hadde de også en uke med en »nyfødt baby« som skrek og krevde stell døgnet rundt. Dette ga diverse situasjoner med frempek til mulige situasjoner husets par, ikke minst Rodney og Annette kunne havne i. De måtte også teatralt spille sin egen potensielle fremtid ved å iføre seg bryllupsklær under en spesiell seremoni. En annen type performativitet hvor produsenten bidro var gjennom spesielle musikalske markeringer. Dels ved å spille musikk som både fungerte stemningsskapende internt $i$ huset og i det ferdig redigerte fjernsynsprogrammet, dels ved å bruke musikk aktivt kommenterende, ikke minst i forhold til sexscener. Ved plutselig å sette på kommenterende musikk idet husets par var i ferd med å avslutte et samleie kunne man produsere et sexsegment med tilstrekkelig »comic relief« til at det kunne passere på prime time TV. Gjennom å klippe til scenen idet musikken kom på kunne man vise nokså lite, og dermed skape en betydelig tilleggsgevinst for nettbrukere og abonnementer på Canal Digitals tre 24 timers kanaler, samt ufarliggjøre det pornografiske elementet med humor ${ }^{12}$. Om morgenen på Annettes bursdag den 1. april klippes det inn mens hun sitter på skrevs over Rodney - man spiller $» V i$ gratulerer og saluterer ...«(02.04.01). En uke senere kommer Britney Spears' Oops! I did it again - som blant annet fortsetter »I'm not that 
innocent« - idet et samleie avsluttes. Annette ble i første sending presentert poserende i en tettsittende rød latex-drakt mens hun sang nettopp denne sangen. Det viste seg å være en heldig etablering. Når sangen nå resirkuleres for fullt volum blir paret pinlig bevisst at de har sex foran en halv million seere.

Her er vi i det performative register hinsides fakta og fiksjon gjennom deltakerne og produsentens tett sammenvevde innsats, selv om det stadig foregår en dokumentasjon for å fange inn resultatet av dette performative samspillet. Vi er samtidig $i$ et obskønt register når unge mennesker »tatt på fersken « $\mathrm{i}$ intime sengeaktiviteter blir prime time familieunderholdning. Samtidig kontres denne pinligheten ved at sex omtales som »naturlig«, hvilket også er ment å implisere at det er »naturlig« at halve det norske fjernsynspublikum ser på. For å få gapet mellom de to områdene for »naturlig« aktivitet til å synes ubetydelig, kreves en meget effektiv selger i programlederfunksjonen. Dette er da også Big Brother's største bedrift: normaliseringen av et kikkerformat som de færreste ville trodd var mulig for få år tilbake.

Deltakerne oppfører også på bestilling fra »Big Brother« (som gir dem beskjeder og oppgaver) en scene fra The Wizard of Oz (Victor Fleming 1939). Dette er motivert av Ramsys macho fremtoning hvor han snakker om å knulle jenter uten å bry seg med dem følelsesmessig, samt av følgende forhistorie: Ramsy fikk tidlig en viss sans for Rebekka og sa han angret på at han ikke hadde hatt sex med henne for hun ble stemt ut, noe han mente hun hadde vært helt klar for (sending 09.03.01). To og en halv uke senere etablerer han et forhold til Anne Mona og de har sex til alle døgnets tider. Her ser produsentene en mulighet til et eksperiment i eksperimentet. De aktiverer såpeoperaens dramaturgi og bringer Rebekka inn igjen (26.04.01). Dermed kommer Ramsy i klemme følelsesmessig. Han får vanskeligheter med å holde ved like interessen for Anne Mona, men han nøler også med å gjenetablere noe forhold til Rebekka selv om hun ser ut til å være interessert. Det er i denne situasjonen at Ramsy, som blir satt til å spille blikkmannen, må be trollmannen fra $\mathrm{Oz}$ om å få et hjerte, noe han ikke har (09.05.01). Scenen gir minimal troverdighet som fiksjon. Den demonstrerer fiksjonens oppløsning i den performative lek hvis hensikt er å stille Ramsys »hjerteløshet« og hans kvaler når det gjelder valg av seksual- og kjærlighetspartner til skue - til underholdning for de som ser situasjonens poeng. Innlagte skuespill som The Wizard of $\mathrm{Oz}$, posering i karaokenummer, eller som brudepar er ment å virke dramaturgisk forsterkende utfra såpeoperaens imaginasjonsverden hvor kjærlighet og svik står sentralt.

Trykket fra eksperimentsituasjonen er så spesielt at deltakerne kan ha vanskeligheter med å orientere seg om hva de føler, og hvordan de vil bedømme relasjonene deres frigjort fra den eksperimentelle situasjonen som har produsert dem som elskende. På spørsmål om Rodney og hun er kjærester kan ikke Annette svare annet enn å si at de har et »situasjonsbetinga forhold« (19.04.01). Husets spesielle eksperimentsituasjon gjør det vanskelig å vurdere hva som kan holde utenfor dets fire vegger. Det samme gir Ramsy uttrykk for ${ }^{13}$.

Gameshow-elementet med særlige innsatser for å vinne styrker også deltakernes performative innsats og programmets performative preg. Spill og konkurranser kan representeres på en dokumentarisk måte, men selve spillet er performativt og dermed hevet over spørsmålet om i hvilken utstrekning det kan rubriseres som fakta eller fiksjon. Vi kan i høyden spørre om en performativ handling som ekspressivt uttrykk for en persons vesen er autentisk eller ikke. Dermed er spørsmålet om fakta og fiksjon plassert på sidelinjen, mens spørsmålet om performativ autentisitet gjerne vektlegges - både i interne vurderinger av hvem som »er den de er«, og i publikums vurderinger av hvem som bør vinne millionen ${ }^{14}$. I det norske Big Brother spilte særlig menn som var opptatt av å markere sin maskulinitet på dette. De sa for eksempel »sånn er jeg bare« (Per Morten), eller »det står jeg 100\% for« (Rodney). Vinneren, Lars Joakim, sto imidlertid for et humoristisk maskespill hvor han kunne spille på flere trekk ved sin personlighet snarere enn å insistere på noen endimensjonal autentisitet. Han var klovn og entertainer og har siden fått jobb som det. Lars Joakims seier representerer således i en viss forstand konseptets nederlag - teatralitetens seier over autentisitets- og overvåkningsparadigmet.

Hvordan fungerer så Big Brother når det gjelder redigering, fremstilles deltakerne på en særlig tendensiøs måte? På redigeringsnivå skiller ikke Big Brother seg vesentlig fra andre dokumentarfilmer når det gjelder teknikker som tas i bruk for å karakterisere personene. I Paul Watsons dokumentarfilm The Fishing Party (1985), som er 
et nidportrett av en gruppe pengesterke Thatcher-tilhengere, ser vi for eksempel nærbilder av hvordan rikingene slurper i seg krabbekjøtt mens skipperen på fiskebåten de har leid må ta til takke med tørre brødskiver. Tilsvarende kan også spising med godt hørbare slurpelyder, pilling i nese, ekstra høy mikrofonlyd idet man synger skjærende falskt f.eks, brukes som karakteriserende elementer i Big Brother. Her er slike virkemidler i større utstrekning enn i dokumentarfilmen del av et standard repertoar siden man gjerne vil se deltakerne dumme seg ut.

\section{Det kannibalske øyet}

Jeg har argumentert for viktigheten av å skille mellom virkelighetsshowene og eksperimentfjernsynet. Mens de førstnevnte formatene i stor utstrekning finner sitt stoff $i$ en virkelighet som foregår uavhengig av kamera (selv om dramatiseringer brukes f.eks i Rescue 911), produseres eksperimentformatene gjennom omfattende casting-prosedyrer, avstengning i et sosialt laboratorium etc ${ }^{15}$. Samtidig som jeg ønsker å understreke forskjellene på de to programtypene og verdien av ulike betegnelser, kan det være grunn til å spørre om de ikke også har vesentlige trekk felles. Kan det for eksempel være slektskap mellom måten vi ser på begge, og i hvilken grad kan de blikk vi ser disse programmene med igjen henge sammen med innsnevringen av det referensielle feltet?

La oss som et første skritt for å besvare disse spørsmålene se nærmere på visse sider ved den fascinasjon og lyst som dokumentarfilmen kan stimulere, en fascinasjon som ikke har fått så mye omtale, da dokumentaren først og fremst har fremstått som rettet mot informasjon og opplysning. Elisabeth Cowie søker å komplettere dette bildet, hun ønsker å undersøke »the extent to which actuality and documentary films involve us as desiring, as well as knowing, spectators" (Cowie 1999:20). Hun knytter denne lysten til uvanlige hendelser og øyeblikk hvor de man ser på avslører seg på ulike måter.

This pleasure in overlooking and overhearing the scene is heightened whenever an action not normally seen in public is shown in a film, or when someone exposes her or his feelings or thoughts on film accidentally or without apparent premeditation, which we are therefore led to read as »genuine.« Such moments may also be comic or embarrassing and, when caught on home video, have become the material for television comedy shows. (ibid.:28)

Harald Eia, komiker og skuespiller, er begeistret over slike genuine øyeblikk i Big Brother, også på mikronivå. »Det er rått å se for eksempel hvordan Per Morten i ett sekund innser at han er en litt slitsom type, for så i neste øyeblikk å gå tilbake til den gamle selvrettferdigheten sin«, sier han (sitert i Tveitereid 2001:25).

Betydelige deler av vår fascinasjon over å kunne se hva som skjer i Big Brother-huset er imidlertid knyttet til voyeuristiske gleder over å se det forbudte representert. Cowie beskriver disse slik: »when the desire to see what is normally hidden or forbidden is associated with pleasure rather than science, that desire is more usually termed voyeurism « (Cowie 1999:28). I voyeurismen er det i følge Cowie snakk om en bestemt form for nysgjerrighet: »Curiosity here implies a seeing without the subject itself being seen $[. .$.$] involving$ a fantasy of mastery« (ibid.:28). George Orwells altseende »Big Brother" er inkarnasjonen av et slikt visuelt herredømme, men lysten forbundet med voyeurismen er også forbundet med det ukjente og erotisk ladede, noe David Lynch formulerer treffende.

Jeg har altid haft en lyst til at snige mig ind i en pikes lejlighed og betragte hende hele natten. Jeg havde en idé om at mens jeg gjorde det, ville jeg se noget, som jeg senere ville opdage var nøglen til et mysterium. Jeg tror man er fascineret af dét, at være istand til at se ind i en verden, man ellers ikke ville kende til. Det er det fantastiske ved film, alle kan blive en voyeur. Voyeurisme er som at se fjernsyn - gå et skridt videre og du har lyst til at se nærmere på ting, som virkelig hænder. (Lynch sitert i Dalgaard et al. 1994:348)

Mens Lynch tematiserer slike interesser i fiksjonsfilm med skuespillere, gjør eksperimentfjernsynet det med »No script, No actors«, som det heter i filmen Edtv (Ron Howard 1999) sitt eksperimentkonsept True TV. Programmets produsent, Cynthia, forteller at hun ble overbevist om at konseptet kom til å fungere da hun »realized that the person we pick, the guy that's on TV all day, doesn't even have to be good. If he's good, great, but if he's bad, even better«. Som hun forklarer: 
People cannot turn away from an accident. I mean, you drive by and you say: I hope there's not a head lying [...] but then you look. You don't want to miss it. So we put a guy on TV and we just sit and wait to see if that head starts rolling down the highway. And that's fun for the whole family.

Analogien til ulykker antyder at vi kan mobilisere et sterkt og komplisert følelsesregister som dels innebærer identifikasjon og empati, men også skrekkblandet fryd og et glupsk blikk som næres av den andres ulykke.

Vi kan glede oss over blottleggingen av personlige og private detaljer både i dokumentarfilmer og i eksperimentformater som Big Brother, men det er oftest ulike forutsetninger som ligger til grunn for denne blottleggingen i de to genrene, for det voyeuristiske blikk som konstitueres og ikke minst for den mulighet til empati som åpner seg overfor de sosiale aktørene. »Identification [...] involves taking up the position of the social actors presented by the documentary so that we are moved by their stories as if they were our own«, sier Cowie (Cowie 1999:30), men hun påpeker samtidig at denne empatiske identifikasjonen ikke råder grunnen alene.

The willingness of members of the public to be filmed - whether in more ostensibly serious observational films or in shows such as You've Been Framed - as well as our pleasure in the confessions and humiliations exposed attest to our wish not to see and hear but also to be heard and seen, for we may identify with the other as heard and as seen in place of ourselves. There arises therefore the pleasure of a certain exhibitionism, though this may also include a certain masochism in thus exposing oneself, while at the same time there is a pleasurable separation, a sadistic pleasure in not being the social actor presented. (ibid.:30f)

Vårt engasjement i vanlige mennesker som deltar i underholdningsprogrammer kan delvis være motivert av en ekshibisjonisme som får utløp gjennom identifikasjonen med dem, men denne kan hurtig vendes til en masochisme eller en sadistisk nytelse av at vi ikke er dem, sier Cowie. Dette er måter å se på som kan genereres både i tilknytning til dokumentarfilmer og i eksperimentformater som Big Brother. Genereres så et slikt bedømmende og eventuelt sadistisk blikk lettere i Big Brother enn i dokumentarfilmer?
I en diskusjon av skuespillerens arbeidsbetingelser foran teaterpublikummet og filmkameraet identifiserer Benjamin en testende holdning knyttet til kameraet. Foran kamera, hevder han, »blir skuespillerens prestasjon underkastet en serie optiske tester [...]. Publikum inntar [...] en betraktende holdning som ikke blir forstyrret av noen som helst personlig kontakt med skuespilleren. Publikum identifiserer seg med skuespilleren ved at det identifiserer seg med apparatet. Det overtar altså apparatets holdning: det tester« (Benjamin 1991:47f). Dette testende blikket er styrket i Big Brother gjennom en rekke forhold. Sentralt står gameshow-elementet hvor både de andre sosiale aktørene og publikum strukturelt er plassert i testerens rolle siden de er gitt oppgaven å nominere og å stemme ut personer. Det testende blikket fremmes også gjennom kameraenes overvåkningsestetikk. Kameraene representerer ikke dermed bare en overvåknings- og testapparatur, men kan også fungere som løgn- eller autentisitetsdetektor ${ }^{16}$.

Vår rolle som testpersonell vanskeliggjør den typen empati Cowie snakker om. Når vi vendes bort fra den empatiske identifikasjon kan dette hurtig slå over i en form for »sadistic pleasure in not being the social actor presented « (Cowie) - samt i gleden over å »see [...] that head [...] rolling down the highway« (Cynthia) enten gleden over særlig pinlige segmenter nytes ved miksepultene i Big Brother-produksjonen eller foran fjernsynsskjermen hjemme. Her kan man nærme seg en infantil sadistisk attityde som ikke er helt ulik den barn demonstrerer når de plukker en vinge av en flue for å se hva som skjer, eller den man i mer voksen alder kan ha overfor sin Sims familie ${ }^{17}$. Deltakerne føler seg også i en viss utstrekning herset med, men korpsånd, mulige sanksjoner og ønsket om eksponering får dem til å finne seg i mye ${ }^{18}$. I NBC's nye eksperimentformat Fear Factor er sadismen mer eksplisitt. Der blir blant annet deltakerne »senket ned i et mørkt hull og dekket med 400 rotter « (Aftenposten, aften, 13.06.2001: 49). De må også love å ikke saksøke NBC om de blir skadet underveis.

»Som utgangspunkt for et moderne fjernsynsprogram finnes $[\ldots]$ ikke nødvendigvis noen som "vil fram med noe'«, sier Espen Ytreberg, »Det hele starter like gjerne med overveininger av typen: Hva slags stoffmiks må vi ha i dette magasinet for å få minst 15\% rating?« (Ytreberg 2000:12). 
I virkelighets- og eksperimentfjernsynet kjenner man denne manipuleringsviljen på kroppen som man kjenner spiralfjærene $\mathrm{i}$ en dårlig madrass. SPECTACLET er i følge Guy Debord »capital accumulated to the point where it becomes image« (Debord 1995:24). I den grad Debords begrep om »SPECTACLE« har relevans for dagens TV har det relevans i tilknytning til de nye virkelighets- og eksperimentformatene. Deres kolonialisering av faktadiskurser for underholdningsformål er nærmest kun motivert av profitthensyn. Kreativiteten har forlatt estetikkens område og er relokalisert i økonomiens verden. Derfor gir arbeid med formatene begrenset prestisje i produksjonsmiljøer - liksom det å lage Pizza Grandiosa ikke inngir respekt i restaurantkretser - derfor kan man også si, i forlengelsen av Debord, at programmene er denne økonomiske interessens estetiske artikulasjon.

Det innebærer imidlertid i følge Debord også en sosial relasjon: »THE SPECTACLE IS NOT a collection of images; rather, it is a social relationship between people that is mediated by images« (Debord 1995:12). Hva er så den sosiale relasjon som blir mediert i eksperimentfjernsynet? Den nye kreativiteten i fjernsynsunderholdningen hvor Big Brother er spydspissen, er fundert på en radikal redefinering av deltakerne fra medmennesker med ansikter overfor hvilke vi er etisk forpliktet (se Lévinas 1995), til funksjoner i et forlystelsesspill hvor vi har kjøpt oss fri fra et slikt sosialt ansvar ved deltakernes potensielle kompensasjon gjennom berømmelse og penger. Den nye friheten er berusende. Vi har da også fått et oppkomme av nye formater. Denne nye kreativitet i fjernsynsunderholdningen iscenesetter en dramatisk utvidelse av hva man kan kjøpe for penger - et mer eller mindre langvarig fritak fra å behandle den andre med respekt. Ikke minst synes det attraktivt å demonstrere at den andres verdighet er til salgs. Lars Joakim, som ble vinneren i det norske Big Brother, demonstrerte en forstålse for grunntonen i denne kreativiteten da han spurte Annette om hun kunne tenke seg å sove på et offentlig toalett i 4 uker for 70000 kroner ${ }^{19}$.

Går vi tilbake til Benjamins skildring av testapparaturen fra det tidlige 1930-tallet gir han følgende kulturanalytiske forklaring på dens fremvekst.

Utvidelsen av testmulighetenes område, som apparaturen betyr for skuespilleren, tilsvarer den enorme utvidelse av testmulighetene som, på grunn av de økonomiske omstendigheter, har skjedd for individets del. Slik vokser stadig betydningen av yrkesopptaksprøver. I slike prøver er det utsnitt av individets prestasjoner som avgjør. Filmopptak og yrkesopptaksprøve foregår foran en jury av fagfolk. Innspillingssjefen i filmatelieret står nøyaktig på den samme plass som forsøkslederen har ved opptaksprøven. (Benjamin 1991: 48)

På mange måter har vi fått et testsamfunn liksom vi har fått et overvåkningssamfunn. Det testende kamera overvåker gater, banker og kropper under operasjon. Det kompletteres av elektronisk overvåkning. Staten overvåker oss som borgere, og kommersielle aktører overvåker oss om mulig enda mer intenst som konsumenter. Psykologiske tester florerer ved tilsettinger og ved utsiling av deltakere til programmer. Den testende TV-teknologien vendes nå også mot testeren, mot voyeuren som nå selv blir sett og testet for sine valg og tildelt reklame deretter ${ }^{20}$. Dette risiko-, test-, og overvåkningssamfunnet strekker seg like inn i kanalen som serverer dets symbolske form, noe som ble iscenesatt idet direktøren i TVNorge ble avsatt dagen før Big Brother-finalen. Han hadde ikke klart å omsette seersuksessen til annonseinntekter. Dessuten motsatte han seg Temptation Island ${ }^{21}$.

Den testende holdning og den manglende empati gir seg også utslag i måten vi snakker om de menneskene vi lærer å kjenne. Mens den empatiske identifikasjon inngir fortrolighet på en måte som gjør at vi ikke føler oss vel med å snakke åpent om alle intime detaljer vi blir kjent med, krever den testende holdning på sin side en rapportering av testenes resultat. Det ligger i sakens natur at vi snakker. Om personene dessuten selv forsøker å skjule ting for oss bidrar deres manglende åpenhet til at vi kan snakke om dem uten å føle at vi svikter deres tillit. Det snakkes derfor ofte med skadefryd i sladderens toneleie. At deltakerne heller ikke har gjort seg »fortjent« til oppmerksomheten ved annet enn å stille sine privatliv til rådighet for å oppnå rikdom, berømmelse og spenning, bidrar også til å posisjonere dem på en måte som lett genererer forakt. Det kan imidlertid også genereres sterke positive følelser for enkelte av deltakerne. Polariseringen mellom positive og negative følelser er ikke helt ulik den som kan utvikle seg i tilknytning til såpeoperakarakterer. Ambivalens og manglende 
stabilitet i slike følelser synes imidlertid mer uttalt i forbindelse med Big Brother.

I tilknytning til det norske Big Brother ble det sagt mye positivt om Lars Joakim, som aldri var truet som vinner ${ }^{22}$. Han ble ikke bare »kjendis«, han ble endatil godt likt. Hans innsats ble, liksom Rodneys og Annettes, kronet med videre arbeid for TVNorge. De har alle tre fått oppfylt en av de viktigste drømmene for de som melder seg som deltakere i eksperimentformatene, en karriere på tv-skjermen. Drømmen om eksponering på tv, om kjendisstatus er blant mange så sterk at de uheldige sidene knyttet til uheldig fremstilling og potensiell hets for mange oppveies uten problemer ${ }^{23}$. Mens Lars Joakim synes å nyte høy respekt, har Rodney og andre blitt offer for omfattende hets, ikke minst på nettet. Det kan derfor være grunn til å spørre hva slags form for berømmelse Big Brother og andre eksperimentformater er egnet til å produsere.

Berømmelsens fundament er her i utgangspunktet (sosial)pornografisk utleverende og testende. Til grunn ligger et arrangement som er ydmykende, ved at lyd og bilde fra deres liv i huset, ikke minst fra deres pinlige øyeblikk, er utlevert. Samtidig er det ærefullt i kraft av at de blir utvalgt i skarp konkurranse med andre, og på grunn av oppmerksomheten de får. De oppfatter seg således som spesielle til tross for at fjernsynsprodusenter, som Cynthia i Edtv, gjerne kan ha valgt dem ut på grunnlaget »if he's bad, even better«. Offentlig liker produsenter bedre å si at deltakerne »har en historie å fortelle« (se Østby 2001). Slik kan deltakernes selvfølelse støttes samtidig som produsenten kan fremstå som hjelper snarere enn en som utnytter attraksjonsverdien ved å »see [...] that head start rolling down the highway«. Samtidig som deltakerne har en viss sårbarhet som gjør at de kan tilby noen emosjonelle kriser, må de også ha styrke nok til at en testpsykolog mener de er istand til å klare seg gjennom den sterke eksponeringen. På dette usikre fundamentet får de en berømmelse uten særlig mye respekt - en ambivalent beundring som hurtig kan svinge mellom hyllest og forakt. I forlengelsen av Cowie kan vi si at beundringen kan romme en viss identifikasjon knyttet til egen ekshibisjonisme, men også en sadistisk glede over ikke å være den eksponerte, en glede som også kan hente næring fra en viss misunnelse. Siden deres »kjendis«-status ikke er forankret i en allment anerkjent prestasjon (som idrettskvinnens, musikerens, skuespillerens og regissørens), men først $\mathrm{og}$ fremst et resultat av den ikke nødvendigvis helt »fortjente« eksponeringen de har fătt, er det lite som forankrer og sikrer deres status. Når Lars Joakim synes å stå i en særstilling kan det igjen knyttes til måten han hevdet seg - som skuespiller og dyktig entertainer mer enn som en som lot sitt privatliv blottlegges og risikerte sin verdighet. Hans særlige status tilhører en hvis hode vi aldri har sett »rolling down the highway«.

Til tross for overvåkning og nyskjerrighet har vi begrenset interesse for de unge menneskenes virkelige liv - liksom vi ikke har inngående interesse for privatlivet til deltakerne i Vil $d u$ bli millioner? Vi retter oftere et kannibalistisk enn et empatisk blikk mot dem. Vi er ikke empatisk interessert i detaljene om deres liv, men testende og tidvis også sadistisk interessert. Derfor er det liten nåde, både i samtalene som føres om deltakerne i intervjumøter på nettet og i chat-grupper. Derfor blir den testende voyeurisme, hvor sadismen og gleden over ydmykelsen ikke er langt unna, mer fremtredende enn den empatiske identifikasjon som kan få bredere plass i dokumentarformater. Derfor kan deltakere bli nådeløst behandlet og bedømt ${ }^{24}$. Med utgangspunkt i et testende kannibalistisk blikk vil mye av informasjonen som virvles opp om deltakerne danne et slags overskudd eller »excess«. I spriket mellom all denne informasjonen som involverer deres virkelige liv - og som på et vis krever reell respekt for et medmenneske - og spillets respektløse omgang med denne informasjonen oppstår en diskrepans som ligner den virkelighetsshowene genererer ved å rekontekstualisere ethvert skjebnesvangert øyeblikk som ren underholdning og dermed fjerne det fra sin historiske sammenheng. Resultatet er i begge tilfeller en delvis suspensjon eller innsnevring av det referensielle feltet - til fordel for den nye friheten til å nyte virkelighetens drama uten forpliktelser overfor den andres skjebne. Her ser vi konturene av det kannibalske øyet.

Takk til Rådet for anvendt medieforskning, Handlingsplanen mot vold $i$ bildemediene og Institusjonen Fritt Ord for finansiell støtte. Feg vil også takke Susanne Østby Sather, Liv Hausken, Kristin Skare Orgeret, Pål Sletaune, Arnt Maasø, Anders Lindstad, Synne Skjulstad, Espen Ytreberg og Janne Bondi Fohannessen for å ha lest og kommentert. 


\section{Noter}

1 På engelsk har begreper som »reality show«, »reality $\mathrm{TV} \ll$ og »reality programming« vært brukt om disse formatene. Jeg foretrekker »reality show«, eller den norske oversettelsen »virkelighetsshow «, som får frem underholdningsaspektet i disse formatene. »Reality $\mathrm{TV}$ « og det norske »virkelighetsfjernsyn« er uheldige begreper på grunn av den tvilsomme virkelighetsoppfating de inviterer til, samt fordi de nærmest impliserer at dokumentarfilm og andre faktadiskurser har et mindre nært forhold til virkeligheten enn programmer som Cops og Real TV.

2 Ofte omtales eksperimentformater også som »reality TV« eller »virkelighetsfjernsyn«, hvilket er forvirrende $\mathrm{i}$ forhold til formatene basert på politi- og redningsarbeid, og lite opplysende om eksperimentets sentrale rolle i konseptene. Mens virkelighetsshowene i utgangspunktet baserer seg på hendelser som ikke er laget for kamera, er det nye formatet basert på mer eller mindre lukkede eksperimentsituasjoner som kontinuerlig kan justeres for å generere formålstjenlig adferd hos deltakerne. Det finnes også et bredere felt av programmer som på ulike måter er virkelighetsorienterte, men som jeg ikke tar opp her, »dokusåper«, »talkshow«, dokumentarserier, videodagbøker etc.

3 Foruten det effektive samvirket mellom nett, telefon og fjernsyn demonstrerer Big Brother også sider ved det digitale fjernsynets kommersielle logikk. Mens det analoge kommersielle fjernsynet er innrettet på å generere »maks seere per krone«, ser medieøkonomen Terje Gaustad en utvikling mot »maks sendeflate per krone« som resultat av det digitale fjernsynets økte sendekapasitet (2001:55). »I så måte er Big Brotherkonseptet rent forretningsmessig meget godt«, hevder han. »Man trenger ingen betalte skuespillere og ingen kostbare skribenter. Til overmål 'arbeider' deltakerne i Big Brother døgnet rundt [...] og [...] får seg til å gjøre ting foran kameraene profesjonelle skuespillere enten ikke ville gjøre eller kreve solid kompensasjon for. De skaper et enormt programvolum som dekker store sendeflater«. Et tankekors, noterer han, er imidlertid at »maks sendeflate per krone« ser ut til å være det digitale fjernsynets effektivitetsmål, hvilket er det motsatte av det mål man vanligvis legger til grunn for å stipulere høy produksjonsverdi eller kvalitet.

Styrk Jansen, som har produsert Baren, påpeker ellers at en viktig drivkraft bak de nye formatene er å få »eierskap til alt innholdet«, som så kan tilrettelegges "for så mange distribusjonskanaler som mulig « (sitert i Ostby Sæther 2001:140). Man satser også på å bygge opp enkelte av deltakernes »kjendis«-status slik at de kan benyttes i senere evenementer og programmer.

4 Man påberoper seg imidlertid stadig en viktig informasjons- og læringsfunksjon. Formatene søkes kontinuerlig legitimert ved at de gir informasjon om trafikk- og brannsikkerhet, eller ved at vi skal forstå »de kriminelles tenkemåte« bedre etc. I Big Brother ble legitimeringsstrategien knyttet til informasjon og læring brutalt punktert av Ramsy, en av deltakerne i det norske Big Brother. På programlederens spørsmål til den som er stemt ut om hva vedkommende har fått ut av å være med på programmet svarer de fleste servilt at de har lært mer om seg selv e.l. Ramsys svar var kort og godt: »sex!«

5 Den økte teledeltagelsen representerer sjelden noen reell styrking av den offentlige samtalen. Et unntak er National Public Radio (NPR) i USA, som har debattprogrammer med kunnskapsrike innringere. Økt deltagelse i ulike kringkastingsmedier kan ikke uten videre betraktes som utrykk for »demokratisering« uten en nærmere vurdering av de kvalitative premisser den økte deltagelsen skjer på.

6 Skal man undersøke hvorvidt virkelighetsshowene har bidratt til å endre og redefinere andre sjangere er kriminalstoffets utforming og volum i nyhetssendinger, voldens plass i naturprogrammer og tendensen til apolitisk og sensasjonspreget stoff i dokumentarfilmen blant elementene man kan se nærmere på. En slik undersøkelse må imidlertid ikke være blind for tidligere tendenser i slik retning. Mondo cane (Paolo Cavara, Gualtiero Jacopetti og Franco E. Prosperi 1962) og den etterfølgende mondo-sjanger er for eksempel en viktig forløper for virkelighetsshowene. Innflydelsen er imidlertid reell nok. I følge Daniel C. Hallin er TVnyheter »increasingly seen as a subgenre of television programming, rather than as a branch of journalism« (1994:110). Programmer som A Current Affair, Hard Copy og Inside Edition er »too successful not to be tempting to those in local and network television news who are also, in the new language of television, in the business of 'reality-based programming' ", sier han (ibid.:179).

7 Myten om »vanlige mennesker« bør ikke tas for alvorlig. Mens vanlige mennesker gjerne »sitter helt stille å ser på«, som Jansen sier, er man mer ute etter noen som »har noe å by på [...] Derfor er det nok et ganske skjevt utvalg som ender opp på tv« (sitert i Østby Sæther 2001:142). Det betyr imidlertid ikke, hevder han, at de leter etter »en bimbo eller en gærning« (ibid.). Som i såpeoperaen søker man imidlertid gjerne konfliktlinjer mellom markant ulike personer.

8 Både på fransk (obscénité) og engelsk (obscenity) fungerer Baudrillards ordspill slik at begrepet både kommer til å referere til det som verken er på eller av scenen, men til noe som i en forstand er hinsides denne, og til det obskøne. Jeg bruker »obscenitet« som en norsk versjon av begrepet.

9 I slike eksperimenter produserer instinktdrevne dyr generaliserbar kunnskap, mennesket i mindre grad siden det er et sosialt dyr. Kontrolleffekten blir stor, effekten av den uvanlige eksperiment- og overvåkningssituasjonen. Selve kamerabevisstheten kan imidlertid synke betydelig og man kan komme til å se folk gjøre ting som få eller ingen ville gjort om de tenkte over at det var kamera tilstede. Både produsentene som redigerer og publikum som ser på er villige til å vente en del på slike »genuine øyeblikk« som kan være fascinerende $\mathrm{i}$ sin naivitet, intimitet og autentisitet.

10 I tilknytning til spesielt attraktive begivenheter er både tabloidpressen, sms-meldinger og rykter viktige for å skape en fornemmelse av at man »må se hva som skjer«, noe som kan bidra til å gi programmet status av en viktig begivenhet som man »må« følge. 
11 Produsentens utfordring ligger ikke minst i å forstå hvordan eksperimentet best kan styres for å oppnå spennende relasjoner og hendelser. Derfor har formatfabrikken Endemol møter hvor man blant annet diskuterer virkemidler for å få mer sex i Big Brother internasjonalt. Både den tyske Big Brother nr. 3 (våren 2001), den franske utgaven Loft Story (våren 2001) og den russiske utgaven Za Steklom (høsten 2001) har funnet måter å stimulere dette på, blant annet gjennom casting, samt ved hjelp av felles senger og ved å knytte seier til pardannelse. »Vi syntes Big Brother var altfor kjedelig «, sier den russiske produsenten Natalja Perova, »Derfor laget vi et program som legger opp til mer erotisk spenning« (sitert i Aale 18.11.2001:11). Russernes policy for nettversjonen tillater nakenhet og sex, ofte gjennom nærbilder, men man klipper vekk noen minutter knyttet til elskovsaktens klimaks (selv om lyden gjerne forblir usensurert).

12 Canal Digital utnyttet denne pornografiske tilleggsgevinsten presist i sin reklame som ble sendt i tilknytning til programmene. Over kamerabilder fra Big Brother's soverom med en halvsovende deltaker, en dusjende kvinne fotografert på skrå ovenfra og Ramsy og Rebekka heftig kyssende på badet (trolig mens Ramsys Anne Mona sov) kom teksten »Hva går du glipp av akkurat nå?«, deretter en dyp mannsstemme som sa: »Canal Digital sender Big Brother 24 timer i døgnet på tre TV-kanaler. Bestill Big Brother VIP-kort og få fullversjonen. Dette er bare begynnelsen«. Den digitale fjernsynsrevolusjonen markedsføres ikke bare her utfra Big Brother's løfte om voyeuristisk og pornografisk tilfredstillelse, men også gjennom en Temptation Islandorientert mulighet for å se utroskap »live«.

13 En slik usikkerhet kan også hefte ved forhold som oppstår i spesielle feriesituasjoner for eksempel, men forholdene i Big Brother-huset er nokså forskjellige fra slike situasjoner gjennom de kraftige virkemidler som er tatt i bruk for å produsere visse typer adferd.

14 Selv markedsfører produsentene det dels som »virkelighet« når de har bruk for å selge den ideen, dels som »såpe « når de har behov for å beskytte seg selv mot anklager om manipulasjon og feilfremstilling. Såpeargumentet kommer også sterkere som et resultat av ønsket om å beskytte deltakerne for det hat de kan utsettes for i ettertid (Rodney fra Big Brother og Elaine fra det første norske Baren har begge mottatt mordtrusler, Linda fra Robinson i 2000 har blitt overfalt).

15 Big Brother og Robinson kan sies å representere et lukket og et mer åpent eksperimentformat. Mens førstnevnte lukker deltakerne inne med kameraene på 24 timer i døgnet og sender resultatet fortløpende på nettet og daglig på fjernsyn - nøyer sistnevnte seg med mindre fysisk avstengning og overvåkning og redigerer hele forløpet sammen i etterkant. Kontinuerlig overvåkning og daglig oppdatering »mens det skjer« gir en sterkere fornemmelse av »liveness«. Strategien er også mer egnet til å skape innhold for flere distribusjonskanaler.

16 Dette elementet er eksplisitt iscenesatt når programverten med støtte i kamera antyder at Rebekka ikke var oppriktig da hun sa til Anne Mona at det ikke var problematisk at hun hadde blitt sammen med Ramsy. Det testende kamera brukes således til å avmåle såpeeksperimentets utvikling. I et annet innslag i torsdagens »live-show« har man en »menneskelig løgndetektor« i studio. I et lite »eksperiment« vurderer hun deltakerne en etter en utfra svarene de gir på spørsmål fra programlederen (10.05.01).

17 »Real-life' simulator/toy«-spill som for eksempel The Sims gir mulighet for å utvikle både omsorg og sadisme. I Andrew Bubs anmeldelse av spillet skriver han: »Ever wanted to plop a few human beings into a fishbowl and watch them? Maybe influence their lives a bit, for good or ill? [...] The Sims is based on the idea that it's fun to play house with dolls, even as an adult, provided those dolls are able to interact independently with each other [...]. You can train them to care for themselves and then set them free to survive while you watch and benevolently aid them - or sadistically mess with them.« http://www.gamepower.com/games/ html/13156review.html (19.06.01)

18 Produsenten presser deltakerne siden dette gjerne medfører sterkere konflikter innad og flere dramatiske øyeblikk. Ydmyker man og plager deltakerne skjer imidlertid ikke det uten motstand. Situasjonen er således preget av en slags terrorbalanse hvor produsenten risikerer opprør om forholdene blir for ille (uten ordentlig mat, drikke og tobakk og med tøffe krav om å stå opp midt på natten etc.). Det skjedde i Big Brother både i USA (2000) og i Danmark (2001). Derfor regulerer produsenten den interne korpsånden, for eksempel ved å dele ut et par kasser øl og litt festlige klær om stemningen skulle bli for depressiv. For produsenten er det således viktig å velge lojale og formbare deltakere som likevel har initiativ. Et høyt kritisk refleksjonsnivå er ikke nødvendigvis noen fordel.

19 Ta med tannbørsten, som er et av Endemols underholdningsformater ledet fra studio har et innslag som er interessant i denne sammenheng. En av gjestene skal overraskes ved at en for henne verdifull gjenstand, en gjenstand som har fulgt henne i lang tid og som først og fremst har affeksjonsverdi skal knuses eller brennes mot at hun får 10000 kroner, noe programverten forteller henne at en kvinne i hennes situasjon har langt mer bruk for. Etter å ha hørt programlederen og store deler av salen rope »knus den« eller »brenn den« taktfast i et minutt bøyer hun så av selv om hun »har valget« og kan beholde gjenstanden. Situasjonen er regissert på et vis som levner henne liten ære om hun beholder »filledingsen « sin, og i alle fall litt penger om hun gir slipp på den. Hva er poenget her? Skal vi lære oss at alt og alle er til salgs? Er segmentet et øvelsesinstrument som skal skape en type menneske som »knows the price of everything and the value of nothing« (Wilde 1948:403)? Skal vi lære oss at det nå kun er penger som har interesse og at prioritering av andre verdier kun er uttrykk for at vi sitter fast i tradisjoner og minner vi må kvitte oss med?

20 Med digitalt fjernsyn kan vi få en situasjon hvor TVvaner brukes til å skreddersy utvalget av reklamer til den som ser på (se Sanders 2001). Slike systemer er allerede delvis implementert på nettet. 
21 Tidligere satte Vidar Nordli-Mathiesen, som direktør i produksjonsselskapet Rubicon TV, sin stilling inn på at selskapet ikke skulle produsere Big Brother. Dette resulterte $\mathrm{i}$ at TVNorge måtte finne seg et nytt produksjonsselskap. Bransjen er preget av en sterk konkurranse hvor kanalene overbyr hverandre med »dristige « konsepter som fjernsynsfolk på en rekke nivåer opplever at de må være med på for å holde seg i arbeid. Internt i bransjen synes nærmest ingen at de kan ta seg råd til å si nei til et konsept som trekker så mange kunder til annonsørene. TV3 som måtte se sin andre versjon av Baren tape i konkurransen med Big Brother svarte høsten 2001 med Temptation Island-varianten Harem. (Mens Temptation Island hadde fire par som en gruppe mannlige og kvinnelige forførere skulle »teste styrken i«, opererer Harem kun med fire kvinner som beiles av menn. Dermed er utroskapselementet fjernet fra sjekkingen.)

Disse konseptene er først og fremst sårbare gjennom den negative oppmerksomheten annonsørene kan pådra seg. Dette ble illustrert ved at sponsorer trakk seg fra den norske Big Brother, og gjennom TVNorges generelle problemer med å omsette seertallene i annonseinntekter (se Supphellen 2001). Det blir derfor viktig å erobre legitimitet, for eksempel gjennom å assosiere seg med ideelle organisasjoner. Således ble innholdet i Big Brother-huset auksjonert bort og pengene gitt til Frelsesarmeen. På denne måten kunne programmet hente legitimitet gjennom tilknytningen til en organisasjon som nyter uvanlig respekt for sitt arbeid. »Vi ser at vi blir utnyttet her. I det ligger det en mulighet til også å lage en policy rundt slike gaver som er holdbar«, kommenterer Jan Størksen i Frelsesarmeen, Templet Korps (personlig epost 30.05.01). Organisasjonen MOT, som »jobber for å skape et varmere og tryggere oppvekstmiljø for barn og ungdom « (http: //www.mot.no/frameset.asp?page=hva_er_mot.asp (14.11.01)), har vært mer villig til å samarbeide med Big Brother.

22 Mye tyder på at TVNorge lot som om Lars Joakim hadde skarp konkurranse for å øke spenningen i programmet, men ikke minst for å øke inntjeningen gjennom de over 2.7 millioner stemmene via telefon, SMS og fax som kom inn i finaleomgangen. http://bigbrotherl.bigbrother.no/frameset.html (14.11.01) Jeg ser ingen grunn til å tvile på at Lars Joakim vant fordi han fikk flest stemmer. Men jeg ser heller ingen grunn til å tro at konkurransen var like jevn som man fremstilte den i finaleprogrammet. Produsenten vil ha klar fordel av å simulere jevne stemmeresultater, både for spenningens og inntjeningens skyld, samt for å styrke selvbildet til de som kommer tapende ut. To navnløse grafiske søyler representerte stemmene til de som i Big Brother-finalen kjempet om førsteplassen. Avstanden mellom søylene ble mindre og mindre utover i programmet ettersom flere stemte. Var dette uttrykk for reelle stemmetall, eller var det produsentens ønske om stigende spenningskurve vi så illustrert? Det er i denne sammenheng interessant å merke seg at Jansen sier at noe av det som debatteres internt i produsentmiljøet er hvorvidt det nå også er tillatt å lyve (Østby Sæther 2001:141).
En rask kikk på tallene antyder at det kan være god økonomi i en manipulativ praksis. Regner man med 300000 stemmer pr. fax (som det ikke betales for) og en gjennomsnittspris mellom kr. 2,10 (vanlig telefon) og 5,00 (SMS) kan inntjeningen via stemmegivning kun på finalen ha kommet opp i 8,52 millioner kroner, hvorav halvparten skulle tilfalle TVNorge. Med en inntekt fra stemmegivning på 4.26 millioner bare på finalen er det grunn til å spørre om ikke et totalt anslag på circa 10 millioner (se Tveitereid 2001) i inntekt på stemmegivningen er altfor lavt. Tilleggsgevinsten skapt gjennom å manipulere med stemmetallene i finaleprogrammet, som fremprovoserte en rekke flere stemmer enn det som ellers ville blitt avgitt, er vanskelig å stipulere. Det kan imidlertid dreie seg om betydelig mer enn den millionen som ble Lars Joakim til del.

23 Hvordan dette henger sammen med medieforståelse, identitet og sosiale ambisjoner er et godt tema for et tverrfaglig forskningsprosjekt. Hvorfor har det blitt så viktig å bli kjendis? Hvordan vurderes alternative strategier for å oppnå dette?

24 Det kan være nyttig å hente frem flere av de erfaringene tidligere deltakere har gjort seg når de kommer ut. Det kan se ut til at det er en betydelig diskrepans mellom det rosenrøde bilde produsenter (og visse deltakere som søker å omsette sin kortvarige berømmelse i penger eller en mer interessant jobb) forsøker å tegne av mulighetene etter deltagelse og det som faktisk er tilfelle. Dette er en oppgave den kritiske journalistikken bør belyse siden en rekke unge mennesker kan komme til å ta beslutninger på tvilsomt grunnlag. Det kan også være på sin plass å styrke de juridiske rettighetene til deltakere $\mathrm{i}$ underholdningsprogrammer. Spørsmålet diskuteres blant annet i rapporten Consenting Adults (Hibberd et al. 2000) fra en forskergruppe ved University of Stirling.

\section{Litteratur}

Althusser, Louis (1971): Lenin and philosophy and other essays, oversatt av Ben Brewster, London: New Left Books.

Barnouw, Erik (1983): Documentary: A History of the Non-Fiction Film, Revised edition. Oxford: Oxford University Press.

Baudrillard, Jean ([1984] 1988): The ecstasy of communication, oversatt av Bernard \& Caroline Schutze, Sylvère Lotringer (red.), New York: Autonomedia.

Beardsley, Monroe ([1958] 1981): Aesthetics: Problems in the Philosophy of Criticism, Indianapolis: Hackett Publishing Company.

Benjamin, Walter ([1931] 1991): »Liten fotografihistorie«, in Walter Benjamin, Kunstverket $i$ reproduksjonsalderen og andre essays, oversatt og redigert av Torodd Karlsten. Oslo: Gyldendal.

Benjamin, Walter ([1936] 1991): »Kunstverket i reproduksjonsalderen«, in Walter Benjamin, Kunstverket $i$ reproduksjonsalderen og andre essays, oversatt og redigert av Torodd Karlsten. Oslo: Gyldendal.

Comolli, Jean-Louis (1980): »Machines of the Visible«, in Teresa de Lauretis og Stephen 
Heath (red.) The Cinematic Apparatus, London: The Macmillan Press.

Cowie, Elizabeth (1999): »The Spectacle of Actuality«, in Jane M. Gaines og Michael Renov (red.) Collecting Visible Evidence, Minneapolis: University of Minnesota Press.

Dalgaard, Iben et al. (red.) (1994): Oje for Oje: En antologi om synet, København: Det Kongelige danske Kunstakademi.

Debord, Guy ([1967] 1995): The Society of the Spectacle, oversatt av Donald Nicholson-Smith. New York: Zone Books.

Fetveit, Arild ([1999] 2002): »Reality TV in the Digital Era: A Paradox in Visual Culture?«, in James Friedman (red.), Reality Squared: Televisual Discourse on the Real, New Brunswick, NJ: Rutgers University Press.

Foucault, Michel (1975): Surveiller et Punir: Naissance de la prison, Paris: Editions Gallimard.

Gaustad, Terje (2001): »Big Brother-økonomien«, Dagens Neringsliv (12. mars):55.

Goffman, Erving (1959): The Presentation of Self in Everyday Life Garden City, N.Y.: Doubleday Anchor books

Grierson, John (1947): Grierson on Documentary, Forsyth Hardy (red.), New York: Harcourt, Brace and Company.

Gunning, Tom (1990): »The Cinema of Attractions: Early Film, Its Spectator and the Avant Garde«, in Thomas Elsaesser (red.), Early Cinema: Space, Frame, Narrative. London: BFI Publishing.

Gunning, Tom (1995): »An Aesthetic of Astonishment: Early Film and the (In)Credulous Spectator«, in Linda Williams (red.), Viewing Positions: Ways of Seeing Film, New Brunswick, NJ: Rutgers University Press.

Hallin, Daniel C. (1994): We Keep America on Top of the World: Television journalism and the public sphere, London and New York: Routledge.

Hibberd, Matthew et al. (red.) (2000): Consenting Adults, Report. London: Broadcasting Standards Commision.

Kilborn, Richard (1994): »How real can you get?: Recent developments in 'reality' television«, in European Fournal of Communication 9.
Lévinas, Emmanuel ([1984]1995): Etik og Uendelighed: Samtaler med Philippe Nemo. Oversatt av Manni Crone. København: Hans Reitzels Forlag.

Musser, Charles ([1990] 1994): The Emergence of Cinema: The American Screen to 1907, Berkeley: University of California Press.

Nichols, Bill (1994): Blurred Boundaries: Questions of Meaning in Contemporary Culture, Bloomington: Indiana University Press.

Sanders, Edmund (2001): »The TV's Eye Is Set on You«, in LA Times, 11.06.01 (sjekket 19.06.01) http: //www.latimes.com/business/cutting/20010611/ t000048643.html

Supphellen, Magne (2001): Holdninger til annonsering $i$ TVprogrammene Big Brother, Harem og Temptation Island: En studie av store norske TV-annonsorer, Executive report, Institutt for strategi og ledelse, Norges Handelshøyskole, Bergen.

Tveitereid, Simen (2001): »'Drittsekk-TV?'«, Aftenposten, 02.06.01.

»Virkelig 'rottent' reality-fjernsyn«, Aftenposten, aften, 13.06.01.

Wilde, Oscar ([1892] 1948): »Lady Windermere's Fan« in The Works of Oscar Wilde 1856-1900, London and Glasgow: Collins.

Williams, Linda (1989): Hard Core: Power, Pleasure and "The Frenzy of the Visible«, Berkeley: Universiety of California Press.

Ytreberg, Espen (2000): Brede smil og spisse albuer: Hvordan fjernsynet overtaler, Oslo: Aschehoug.

Østby Sæther, Susanne (2001): »Virkelighets-tv: Intervju med Styrk Jansen«, in Norsk Medietidsskrift 8(2).

Aale, Per Kristian (2001): »Umulig å unngå sex«, in Aftenposten, 18.11.01.

Arild Fetveit er Førsteamanuensis på Institut for Medier og Kommunikation ved Oslo Universitet. 